\title{
Seroepidemiological studies of equine herpesviruses 1 (EHV-1) and 4 (EHV-4) infections in working horses from the eastern Turkey
}

\author{
Veysel Soydal ATASEVEN ${ }^{1}$, Seval BILGE-DAĞ $\breve{A L P}^{2}$, Zeynep BAŞARAN ${ }^{3}$, Sıddık KESKIN ${ }^{4}$ \\ ${ }^{1}$ Mustafa Kemal University, Faculty of Veterinary Medicine, Department of Virology, Hatay, Turkey; ${ }^{2}$ Ankara University, Faculty \\ of Veterinary Medicine, Department of Virology, Ankara, Turkey; ${ }^{3}$ Yüzüncü Yıl University, Faculty of Veterinary Medicine, \\ Department of Virology, Van, Turkey; ${ }^{4}$ Yüzüncü Yll University, Faculty of Medicine, Department of Biostatistic, Van, Turkey.
}

\begin{abstract}
Summary: The objective of this research was to determine the presence of equine herpesvirus types 1 (EHV-1) and 4 (EHV4) antibodies in local horses from five provinces in the East Anatolia region of Turkey. Blood samples were collected from 405 nonvaccinated horses living in Van, Bitlis, Muş, Erzurum, and Iğdır, and were analyzed via a commercial enzyme-linked immunosorbent assay (ELISA). EHV-1- and EHV-4-specific antibodies were detected in $94(23.2 \%)$ and $316(78.0 \%)$ of the 405 tested sera, respectively. The seropositivity percentages for EHV-1-specific antibodies by province were as follows: $29.5 \%$ in Van, $6.1 \%$ in Bitlis, $5.1 \%$ in Muş, $24.0 \%$ in Iğdır, and 20.6\% in Erzurum. EHV-4-specific antibodies were detected at levels of $87.2 \%$ in Van, $61.2 \%$ in Bitlis, $56.4 \%$ in Muş, 84.0\% in Iğdır, and 52.9\% in Erzurum. The present investigation demonstrated that EHV-1 and EHV4 infections were more prevalent in the indigenous horse population from five provinces in the East Anatolia region of Turkey. Also, this data on the high seropositivity of both infections in two provinces (Van and Iğdır) along the eastern border of Turkey may be also serve as a risk indicator for future introductions of some transboundary diseases via border trade.
\end{abstract}

Key words: Antibody, equine herpesvirus type-1, equine herpesvirus type-4, Turkey.

\section{Türkiye'nin doğu illerindeki yük atlarında at herpesvirus 1 (EHV-1) ve 4 (EHV-4) infeksiyonlarının seroepidemiyolojisi}

Özet: Bu araştırmada, Türkiye'nin Doğu Anadolu bölgesinde yer alan 5 ilde kullanılan lokal ırk atlarda, at herpesvirus tip-1 (EHV-1) ve 4 (EHV-4)'e karşı oluşmuş antikorların varlığının belirlenmesi amaçlandı. Van, Bitlis, Muş, Erzurum ve Iğdır illerindeki aşılanmamış toplam 405 attan toplanan kan örnekleri ticari bir ELISA kiti ile test edildi. Test edilen serumların, 94 adedi (\%23.2) EHV-1; 316 adedi ise (\%78) EHV-4 antikorları yönünden pozitif bulundu. İllere göre EHV-1 seropozitiflik oranlar1; Van'da \%29.5, Bitlis'te \%6.1, Muş'ta \%5.1, Iğdır'da \%24 ve Erzurum'da \%20.6 olarak tespit edilirken, EHV-4 için seropozitiflik oranları; Van'da \%87.2, Bitlis'te \%61.2, Muş'ta \%56.4, Iğdır'da \%84 ve Erzurum'da \%52.9 olarak saptandı. Bu araştırma, EHV-1 ve EHV-4 infeksiyonlarının Doğu Anadolu bölgesine ait 5 ildeki lokal at populasyonlarında oldukça yaygın olduğunu ortaya koymuştur. Ayrıca, Türkiye'nin doğu sınırında yer alan iki ilde (Van ve Iğdır) her iki infeksiyona karşı belirlenen yüksek seropozitifliğin, gelecekte birçok önemli hastalığın sınır ticareti yolu ile ülkemize girişine yönelik risk oluşturabileceği sonucuna da varılmıştır.

Anahtar sözcükler: Antikor, at herpesvirus tip-1, at herpesvirus tip- 4, Türkiye.

\section{Introduction}

Equine herpesvirus type 1 (EHV-1) and equine herpesvirus type 4 (EHV-4) are members of Alphaherpesviruses and often result in offspring abortion, neonatal foal disease, and paralysis as well as decreases in performance due to respiratory tract disease, leading to significant economic losses (9). EHV-4 causes respiratory disease in young horses, and occasionally abortion and neonatal infection in pregnant mares. EHV-1 is well known as a cause of respiratory tract diseases, outbreaks of abortion, neonatal death, and neurological disease. Both viruses are transmitted via aerosol droplets and direct contact between infected and naïve animals $(9,13)$. Epidemic or sporadic abortions and perinatal/neonatal deaths give rise to considerable economic losses in the equine industry (8).

EHV-1 and EHV-4 can establish latent infections that persist for the lifetime of host, which is a characteristic of all herpesviruses (15). Deleterious factors, such as adverse environmental conditions, corticosteroid treatment, stressful work situations, and population structure and density, can increase the reactivation possibility of herpesviruses (6). The contention policy of EHV-1 and EHV-4 infections includes the effective diagnosis, control, and prevention of these diseases (13). However, serological techniques have been indicated as important tools in epidemiological investigations of equine herpesvirus infections $(3,10,16)$. 
The aim of this study was to investigate the serological evidence for EHV-1 and EHV-4 infections in local working horses from five provinces on the East Anatolia region of Turkey by the enzyme-linked immunosorbent assay (ELISA).

\section{Materials and Methods}

Sampled population and study area: A total of 405 non-vaccinated horses that appeared healthy were sampled. The specimens were taken from random, unregistered animals in small private ownerships from five provinces in East Anatolia region of Turkey. The distribution of sera according to sampling location is shown in Table 1 and Figure 1. A spot of horse sera $(n=108)$ sampled from the Van province was also examined in a previous study by Ataseven et al. (3). Sampling locations had cold climate characteristics similar to other locations in the Eastern Anatolia region of Turkey, with an average altitude of $2000 \mathrm{~m}$ (obtained from the Turkish State of Meteorological Service, Ankara, unpublished data).

Enzyme-linked immunosorbent assay (ELISA): Sera diluted 1/100 were tested using a commercial typespecific EHV-1 and EHV-4 diagnostic ELISA kit (Svanovir ${ }^{\circledR}$, Svanova AB, Sweden). The detection and discrimination of EHV-1 and EHV-4 specific antibodies were done as described by the manufacturer. Samples with OD values $>0.20$ were considered positive, as indicated in the kit procedure.
Statistical analysis: The seroprevalence results for EHV-1 and EHV-4 are expressed in percentages (\%). A chi-square $\left(\chi^{2}\right)$ test was used to determine the association between the seroprevalence results of the five provinces. Then, $\mathrm{Z}$ test was used to determine differences among the seroprevalence proportions of five provinces. The overall data analysis was performed using MINITAB (Ver.14) statistical programme.

Table 1. Distribution of EHV-1 and EHV-4 spesific antibodies according to five provinces.

Tablo 1. İllere göre EHV-1 ve EHV-4 spesifik antikorların dağılımı.

\begin{tabular}{|c|c|c|c|c|}
\hline Province & $\begin{array}{c}\text { Tested } \\
\text { sera no. }\end{array}$ & $\begin{array}{c}\text { Ab to EHV- } \\
1 \\
(\%)\end{array}$ & $\begin{array}{l}\text { Ab to } \\
\text { EHV-4 } \\
(\%)\end{array}$ & $\begin{array}{c}\text { Ab to } \\
\text { EHV-1 and } \\
\text { EHV-4 } \\
(\%)\end{array}$ \\
\hline VAN & 258 & $\begin{array}{c}76 \\
(29.5)\end{array}$ & $\begin{array}{c}225 \\
(87.2)\end{array}$ & $\begin{array}{c}43 \\
(16.7)\end{array}$ \\
\hline BİTLİS & 49 & $\begin{array}{c}3 \\
(6.1)\end{array}$ & $\begin{array}{c}30 \\
(61.2)\end{array}$ & $\begin{array}{c}2 \\
(4.1)\end{array}$ \\
\hline MUŞ & 39 & $\begin{array}{c}2 \\
(5.1)\end{array}$ & $\begin{array}{c}22 \\
(56.4)\end{array}$ & $\begin{array}{c}1 \\
(2.6)\end{array}$ \\
\hline IĞDIR & 25 & $\begin{array}{c}6 \\
(24.0)\end{array}$ & $\begin{array}{c}21 \\
(84.0)\end{array}$ & $\begin{array}{c}4 \\
(16.0)\end{array}$ \\
\hline ERZURUM & 34 & $\begin{array}{c}7 \\
(20.6)\end{array}$ & $\begin{array}{c}18 \\
(52.9)\end{array}$ & $\begin{array}{c}4 \\
(11.8)\end{array}$ \\
\hline \multicolumn{2}{|c|}{ The chi-square $\left(\chi^{2}\right)$} & 20.97 & 61.54 & \\
\hline \multicolumn{2}{|l|}{ DF } & $\begin{array}{c}4 \\
p<0.01\end{array}$ & $\begin{array}{c}\quad 4 \\
p<0.01\end{array}$ & \\
\hline Total & 405 & $\begin{array}{c}94 \\
(23.2)\end{array}$ & $\begin{array}{c}316 \\
(78.0)\end{array}$ & $\begin{array}{c}54 \\
(13.3)\end{array}$ \\
\hline
\end{tabular}

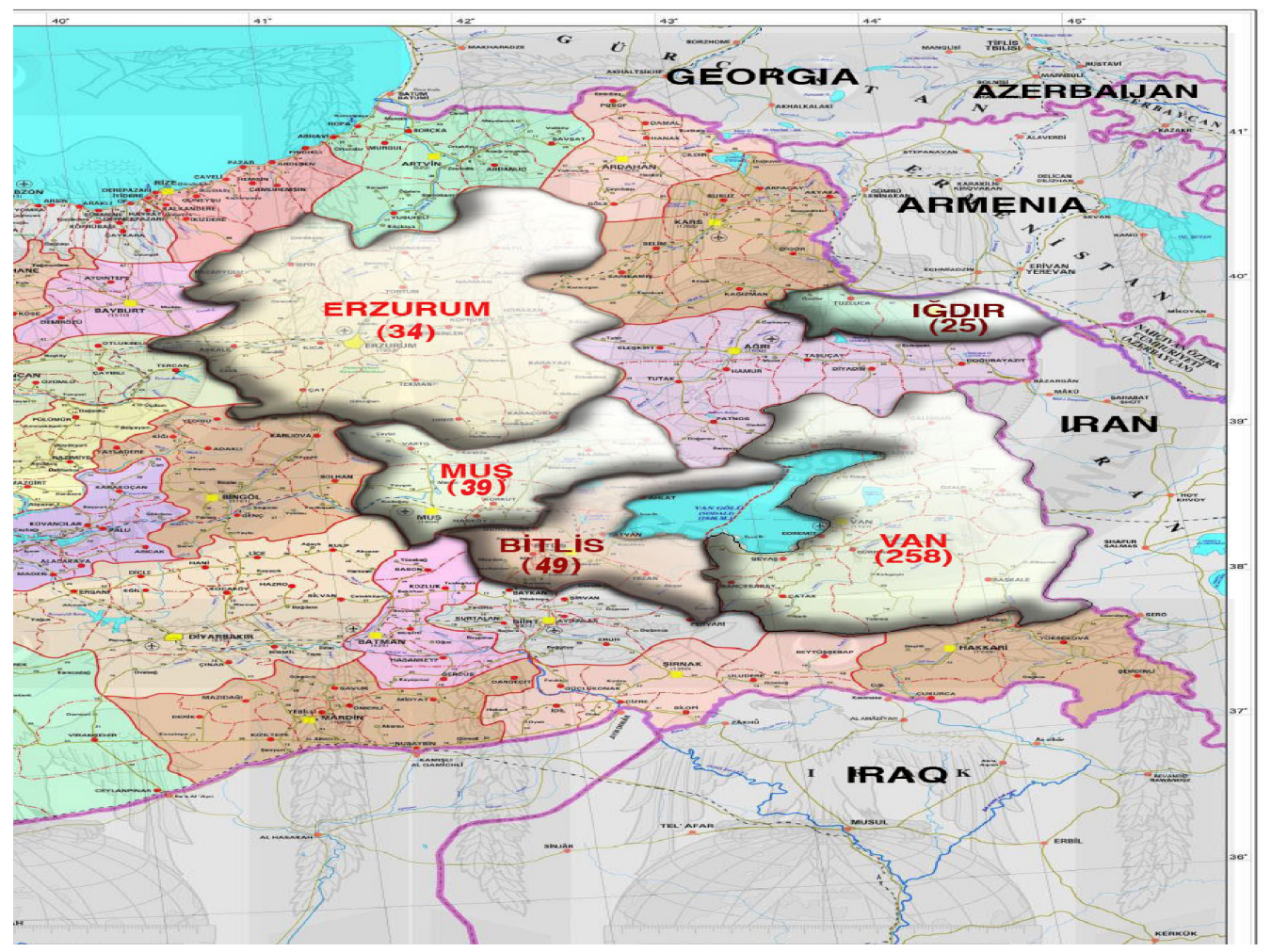

Figure 1. The localization of sampled provinces in the geographical Turkey map.

Şekil 1. Örnekleme yapılan illerin Türkiye haritasındaki coğrafi konumları. 
Table 2. Comparison of five provinces according to proportion values.

Tablo 2. EHV-1 ve EHV-4 görülme oranları bakımından illerin karşılaştırılması.

\begin{tabular}{lcccc}
\hline & \multicolumn{2}{c}{ EHV-1 } & \multicolumn{2}{c}{ EHV-4 } \\
\hline & Z value & P value & Z value & P value \\
\cline { 2 - 5 } Van - Bitlis & 5.25 & $<0.01$ & 4.16 & $<0.01$ \\
Van - Iğdır & 0.61 & 0.544 & 0.94 & 0.348 \\
Van-Muş & 5.37 & $<0.01$ & 4.26 & $<0.01$ \\
Van- Erzurum & 1.18 & 0.237 & 4.36 & $<0.01$ \\
Bitlis - Iğdır & 1.94 & 0.052 & 2.25 & $<0.05$ \\
Bitlis - Muş & 0.20 & 0.84 & 0.46 & 0.648 \\
Bitlis -Erzurum & 1.87 & 0.61 & 0.75 & 0.453 \\
Iğdır-Muş & 2.04 & $<0.05$ & 2.55 & $<0.05$ \\
Iğdır- Erzurum & 0.31 & 0.756 & 2.76 & $<0.01$ \\
Muş-Erzurum & 1.99 & $<0.05$ & 0.30 & 0.766 \\
\hline
\end{tabular}

\section{Results}

A total of 405 serum samples were tested for EHV1 and EHV-4 specific antibodies using ELISA. Overall results revealed that $23.2 \%(94 / 405)$ of the horses sampled were EHV-1 seropositive, while antibodies specific to EHV-4 were detected in $78.0 \%(316 / 405)$ of sera samples. Specific antibodies against both EHV-1 and EHV-4 were found in 13.3\% (54/405). Differences in EHV-1 and EHV-4 antibody prevalences between the border provinces (Van and Iğdır) and other locations were found to be statistically significant $(\mathrm{p}<0.01)$. The rates of EHV-1- and EHV-4-specific antibody presence were higher in the Van and Iğdır provinces, located along the border of Turkey with Iran, than in other provinces. These data were shown in Table 1 and 2.

\section{Discussion and Conclusion}

EHV-1 and EHV-4 infections are ubiquitous in all equid populations worldwide. The detection of EHV-1 and EHV-4 specific antibodies is an important indicator in epidemiological investigations of these Alphaherpesviruses, particularly to determine the asymptomatic carriers within the equine population $(3,12)$. The identification of horses with antibodies specific against EHV-1 and EHV-4 was not previously successful due to the close genetic and serological relationships between EHV-1 and EHV-4 (11). In the present study, the seroprevalence of EHV-1 and EHV-4 infections was determined using a type-specific commercial ELISA to distinguish EHV-1and EHV-4-specific antibodies. Several epidemiological investigations have been performed to elucidate the prevalence of EHV-1 and EHV-4 on a global-scale. Seroprevalence rates for EHV-1 and EHV-4 were reported to be between $8 \%$ and $85.2 \%(4,8,10,12,14)$ and over $\sim 90 \%$, respectively $(8,12)$. The seroprevalences of EHV-1 and EHV-4 were previously reported to be
$14.5 \%$ and $81.7 \%$, respectively, for the sampled horse population in Turkey (3). This study reveals that the horse population in the eastern region of Turkey consisted of $23.2 \% \quad$ EHV-1 and $78.0 \%$ EHV-4. Interestingly, there were great variations in the prevalence values, which fluctuated according to province borders. A number of EHV-1 and EHV-4 antibody-positive horses were found at much higher, statistically significant rates $(p<0.01)$ in the Van and Iğdır provinces, which share a border with Iran, than in other provinces of Turkey. The progression of equine herpesviruses is associated with factors including climate conditions, management activities, population status, transport, and other infections (13). Although EHV-1 and EHV-4 infections are not vector-borne, the cold climate is a stressor for horses that can result in reactivation of latent infections $(6,7,12,16)$. However, the high seroprevalence rates of this region may also be related to the relatively high number of horses per house $(\geq 10$ head), new herds in the region, stressful working conditions, climatic extremes, as well as disease spread due to illegal border trade. One particularly likely explanation for the high seroprevalence detected in the present study is the illegal border transfer of horses in Turkey with Iran; however, the situation in Iran regarding EHV-1 and EHV-4 infections is unknown. Transboundary and emerging diseases are becoming more critical issues, since such infections can rapidly spread throughout an entire region and cause to be interrupted in the international horse trade (5). For instance, the importance of border control and quarantine for babesia and equine influenza infections in horses from eastern border of Turkey has been emphasized by Akkan et al. (1) and Ataseven et al. (2).

Vaccination against EHV-1 and EHV-4 infections has not resulted in the total elimination of these infections in horses. Therefore, other preventive and regulation measures, such as reducing stress factors, limiting the introduction of infection to susceptible healthy animals, reducing the dissemination of infection, and confining infections to a certain area, should be essential parts of an effective infection control program.

Depending on the geographic and economic characteristics, there can be a relatively large number of equids reared in particular areas of Turkey (15). Although the number of samples collected in this study is somewhat limited, the data obtained is still useful as a proxy for the infection situation in this region of Turkey. These results demonstrate that EHV-1 and EHV-4 infections were more prevalent in horses living in eastern region of Turkey and, furthermore, that the detectable high seropositivity along the eastern border of Turkey might serve as a risk indicator for the introduction of transboundary diseases. 


\section{References}

1. Akkan HA, Karaca M, Tütüncü M, Değer S, Keleş İ, Ağaoğlu Z (2003). Serologic and microscopic studies on babesiosis in horse in the eastern border of Turkey. $\mathrm{J}$ Eq Vet Sci, 23, 181-183.

2. Ataseven VS, Daly JM (2007). Seroepidemiology of equine influenza virus infection in Turkey. Turk $\mathrm{J}$ Vet Anim Sci, 31, 199-202.

3. Ataseven VS, Bilge-Dağalp S, Güzel M, Başaran Z, Tan MT, Geraghty B (2008). Prevalence of equine herpesvirus-1 and equine herpesvirus-4 infections in equidae species in Turkey as determined by ELISA and multiplex nested PCR. Res Vet Sci, doi:10.1016/j.rvsc.2008.06.001, in press.

4. Doll ER, Bryans JT (1963). Epizootiology of equine viral rhinopneumonitis. J Am Vet Med Assoc, 142, 31-37.

5. Domenech J, Lubroth J, Eddi C, Martin V, Roger F (2006). Regional and international approaches on prevention and control of animal transboundry and emerging diseases. Ann NY Acad Sci, 1081, 90-107.

6. Foote CE, Gilkerson JR, Whalley JM, Love DN (2003). Seroprevalence of equine herpesvirus 1 in mares and foals on a large Hunter Valley stud farm in years pre-and postvaccination. Aust Vet J, 81, 283-288.

7. Gilkerson JR, Jorm LR, Love DN, Lawrence GL, Whalley JM (1994). Epidemiological investigation of equids herpevirus-4 (EHV-4) excretion assessed by nasal swabs taken from thoroughbred foals. Vet Microbiol, 39, 275-283.

8. Gilkerson JR, Whalley JM, Drummer HE, Studdert MJ, Love DN (1999). Epidemiology of EHV-1 and EHV-4 in the mare and foal populations on a Hunter Valley stud farm: are mares the source of EHV-1 for unweaned foals. Vet Microbiol, 68, 27-34.

9. Harless W and Pusterla N (2006). Equine herpesvirus 1 and 4 respiratory disease in the horse. Clin Tech Eq Pract, 5, 197-202.

10. Keane DP, Little PB, Wilkie BN, Artsob H, Thorsen J (1988). Agents of equine viral encephalomyelitis: correlation of serum and cerebrospinal fluid antibodies. Can J Vet Res, 52, 229-235.
11. Matsumura T, Sugiura T, Imagawa H, Fukunaga Y, Kamada M (1992). Epizootiological aspects of type 1 and type 4 equine herpesvirus infections among horse populations. J Vet Med Sci, 54, 207-211.

12. Nordengrahn A, Merza M, Svedlund G, Roneus M, Berndtsson T, Lindholm A, Drummer HE, Studdert MJ, Abusugra I, Gunnarsson E, Klingeborn B (1999). A field study of the application of a type-spesific test distinguishing antibodies to equine herpesvirus-4 and -1 . 125-128. In: U Wernery, JF Wade, JA Mumford, O-R Kaaden (Eds), Equine Infectious Diseases, Proceedings of the 8th International Conference Equine Infectious Diseases. R\&W Publications, Newmarket.

13. OIE (2000). Equine rhinopneumonitis. www.oie.int/eng/ normes/mmanual/ancien_manuel/A_00075.htm. Erişim Tarihi: 26/02/2008.

14. Singh BK, Yadav MP, Uppal PK, Rattan B (1999). National assessment of equine herpesvirus-1 infection among equidae in India. 578-579. In: U Wernery, JF Wade, JA Mumford, O-R Kaaden (Eds), Equine Infectious Diseases, Proceedings of the 8th International Conference Equine Infectious Diseases. R\&W Publications, Newmarket.

15. TÜİK (2006). Hayvancilı verileri. http:/tuik.gov.tr/ report/rwservlet?hayvancilik. Erişim Tarihi: 08.04.2008

16. Welch HM, Bridges CG, Lyon AM, Griffiths L, Edington N (1992). Latent equid herpesvirus 1 and 4: detection and distinction using the polymerase chain reaction and co-cultivation from lymphoid tissues. $\mathrm{J}$ Gen Virol, 73, 261-268.

Geliş̧ tarihi: 31.01.2009 / Kabul tarihi: 17.07.2009

Address for correspondence:

Yrd. Doç.Dr. Veysel Soydal Ataseven Mustafa Kemal Üniversitesi Veteriner Fakültesi Viroloji Anabilim Dall, Tayfur Sökmen Kampüsü, Antakya/Hatay,

Phone: +90 326 2455845/1516, Fax: +90 3262455704

E-mail:soydalata@hotmail.com 